\title{
Ecological and biological conformity of conditions of the brewing barley cultivation zone
}

\author{
O. Gorash, R. Klymyshena*, V. Khomina, L. Vilchynska \\ Podilsky State Agrarian and Technical University, \\ Shevchenko St., 13, Kamianets-Podilskyi, 32300, Khmelnytskyi region, Ukraine \\ ORCID ID: 0000-0002-4643-7895 \\ E-mail: rita24@i.ua
}

Received: 10.02.2020 Accepted 10.03.2020

\begin{abstract}
The correspondence of agro-ecological and climatic factors of the external environment of the industrial zone of brewing barley to the biological requirements of barley culture has been analyzed. The peculiarity of brewing barley in the formation of the crop and its quality is characterized by the necessity of directing, in the process of photosynthesis, the accumulation of the carbohydrate component of the grain more than in the protein content. The important role of ensuring these requirements depends mainly on the PAR of the long-wavelength range, especially during the second half of the growing season, during the growth and development of the grain. At this time, an important factor in ensuring the brewing quality of barley is the moisture supply of soil moisture, as it depends on the growth process of the grain. The barley culture belongs to the early spring cereals. Due to the changes in climatic conditions, which is directly related to the zone of industrial brewing of barley by analysis of ten-year temperature data, the favorable conditions for the growth and development of barley, the conditions of sowing in early spring have been found. In particular, sowing time is actually possible 20-25 days earlier than traditional, this is the first and second ten days of March. Conducted trial reconnaissance crops in the first decade of March ensured the effective development of plants and the formation of crops favorable to meet the quality requirements for the cultivation of products for the production of malt. The vegetative period of development before the onset of the generative has increased in plants up to 45 days, which by itself is a rather positive component of the efficiency of cultivation technology according to the results of the analysis of climatic factors of the zone of industrial production of brewing barley. As a result of analytical studies the improvement of ecological and biological compliance of spring barley development for the period 2010-2019 has been revealed. Due to the early onset of heat in March, there was a need to make adjustments to certain elements of technology based on appropriate research to ensure effective implementation of the agroecological resource of the area. The urgent tasks, with the aim of balanced processes of spring barley development to energy conditions of the environment, are research with seeding rate, row spacing, depth of seeds wrapping, application of mineral fertilizers.
\end{abstract}

Key words: Barley spring brewing; Factors of vegetation; Light regime; Temperature regime; Soils; Moisture supply; Agroecourses; Growing zone

\section{Introduction}

Agricultural production is interconnected with the need for agro-meteorological and agro-climatic conditions for plant development (Lipinski et al., 2003; Blizniuk et al., 2019)]. The seasonality of field work is conditioned by the cyclical nature of environmental resources (Lipinski et al., 2003). The leading factors of influence include solar radiation and the dynamics of air temperature and the surface of the soil cover that depend on it. Crop production is diverse in its specificity due to the objective reality of the external environment in ensuring the formation of biological objects within agroecosystems. The biological development of the objects corresponds to the properties of solar radiation, thermal regime, atmospheric and soil moisture. Accordingly, these factors determine the composition, structure, geographical location of field crops and the corresponding crop rotation areas. The requirement in the specialization of agricultural production and the objects of crop production in the coincidence of phenophases of development with the dynamics of realization of agro-climatic resources remains quite important. Such correspondence directly to agroclimatic resources, together with the volume of their potential, place in the characterization of the degree of favorableness to the level of productivity and quality of the grown products.

Due to the versatility of agricultural production and the diversity of biological objects to which the crops belong, there is a real opportunity to make rational use of the agro-climatic potential of Ukraine. Characteristic signs of agroecore resources of the environment are the beginning, duration and end of the growing season. The vegetative cycle of plants covers a period during which they reproduce the biological material necessary to preserve the species and at the same time to meet the needs of human life. The rational use of agro-resources of soil and ecological conditions is the basis of the strategy of specialized plant growing.

The steady increase in crop productivity is driven by ecological and biological correspondence between plants and the environment (Medvid and Boyko, 1993). The fundamental basis of crop production is the biological mechanism of crop species to transform the energy of sunlight into the energy of covalent bonds of biopolymers. Agrophytocenosis is an organized system that effectively uses vegetation factors: light, moisture, heat, which are related to abiotic environmental factors. Sunlight is a source of energy for the processes of plant metabolism that undergo plastic and energy metabolism. The limiting factor, first and foremost, is the amount of sunlight energy per unit area of sowing. Temperature regime, moisture supply in the respective macros of the specialization of 
Ukrainian agriculture are ambiguous by year. The inflow of solar radiation, the light period of the specialization zones occupying a certain spatial position, is stable (Polupan et al., 2005). The concept of crop specialization in the agrarian sector of the Ukrainian economy is based on strategic decisions as a result of the achievements of agrarian science to increase efficiency and stabilize production development in relation to adaptation and adaptation of biotypes to environmental factors.

\section{Methods}

The method is based on the importance of the priority of soil and ecological resources and bioclimatic principles of growing crops specializationin accordance with their biological requirements and needs. The factors of vegetation, as important ecological factors in ensuring the productivity of plants, types of soils, fertility, their structure are taken into account. Scientific information on the interconnection of plant biochemical processes with climate biosynthetic potential has also been used. Consideration is given to the zoning of the need to carefully consider the spatial distribution of the major environmental factors that determine the productivity of crops, which gives a comprehensive view of the agricultural production quality of the selected regions (Polupan and Solovey, 1997). On the basis of basic researches functional dependence of realization of biological potential of cultivated plants on ecologicallyquantitative resources of environmental conditions has been established (Polupan et al., 2003). Accordingly, the natural environment of the zone of industrial brewing of barley is analyzed on the basis of the argumentation of certain abiotic factors in accordance with the principle of organization of agrophytocenoses favorable to the formation of high quality of the grown products.

\section{Discussion}

The conditions for growing barley are determined not only by the general need for a resource of vegetation factors for culture at an appropriate level, but also by the specificity of product quality, which is the basis for the specialization of the parameters of the factors of technology intensification. An important role is played by the internal structure of the agroclimatic quality resource within the selected area. The same agroclimatic resources of the growing season can cause not only different levels of productivity, but also different quality of the grown products. It depends on the coincidence of the dynamics of these indicators and the need for development, in particular the barley in the favorable to quality.

According to the terminology of growth and development of higher plants phenophases, in particular, related to barley, come one after another in the cycle of individual development. Factors that are not amenable to human control are the main influence on this process, such as photosynthetic active radiation, effective temperatures and photoperiod.

When evaluating the brewery barley growing zone, it is important to pay attention to the regulation of plant growth and development, which is controlled by environmental conditions, in particular the temperature and duration of the daylight period. For barley, this is due to the regulatory function of the timing of the vegetative organs development and the formation of reproductive organs. Such dependence has arisen and has become entrenched as an adaptive reaction of ontogenesis, which ensures the combination of periods of active life and corresponding stages of individual plant development with the most favorable period of the year. It is undeniable that the biological characteristics of barley were formed in the prehistoric and historical periods in the respective centers of origin. Under what ecological and geographical conditions the barley was formed, it is not known as a biological species.

Modern varieties of spring brewing barley represent the pinnacle of evolution of the Hordeum genus. In biological features, they are significantly different from their ancient ancestors. The cultural species of Hordeum sativum refers to plants of high crop culture, which are required to provide available nutrients from the very beginning of development. With regard to the heat demand of barley among cereals it is undemanding, within the range of $5-15^{\circ} \mathrm{C}$ it meets the lowest level of these values.

Spring barley can be grown in most of the macro specialties of Ukraine's agricultural specialization, which are allocated accordingly for soil and climatic factors, but not brewing. The importance of the chosen area of specialization, in particular the production of brewery barley is to ensure the concentration of industrial malt production. The specialization and concentration of brewing barley is, first and foremost, very much related to the specificities of grain quality requirements, which are regulated by the EU standards. The specificity of brewing barley technology requires fertile structured soils. Formation of spring barley crops favorable for ensuring both high grain yield and proper brewing quality is based on the implementation of the tillering process. Barley bush poorly on acidic soils, which also reduce the field germination of seeds and plant survival.

An important thermal regime of soils, which is highly dependent on the absorption of especially phosphorus. Phosphorus is known to be very slowly absorbed under reduced soil temperature. Due to the high humus content, dark colour, good parametric characteristic of granulometric composition, black soil after the first winter or spring warming well retains heat, which provides early spring sowing - one of the first guarantees to get a high yield. As a rule, in the western Forest-steppe conditions after early sowing often cold comes, black soils retaining the accumulated heat more predetermine the growth of the root system than the stem.

An important feature that needs to be addressed in order to ensure optimal conditions for growing brewing barley is the need for early sowing. In spring barley, genetically fixed adaptation of ontogenesis to environmental conditions results in the regulation of growth and development depending on the temperature factor and the duration of the day.

Short spring days play an important role in vegetation, when sowing is carried out in the first half of March, namely they contribute to the weakening of the apical dominance of the main stem due to the ratio of stimulants and inhibitors of growth and development during which the tillering becomes longer, improving lateral development. Implementation of the biological process of barley tillering promotes the formation of better crops of optical density. Accordingly, it is undisputed that the increase in the duration of the period of vegetative development will greatly contribute to the formation of high-yielding crops aligned on the constituent elementary structural units - stems of plants (Křen et al., 2013; Noworlink and Leszczynska, 2000). According to phenological observations it is established that the start of the stem elongation - the period of generative development onset of spring barley in the conditions of western and central Forest-steppe of Ukraine occurs mainly in the second half of the third decade of May. The same period is actually similar in terms of its occurrence during the development of spring barley in Western Europe. However, the mass sowing, the terms of its holding are quite late in our country. The peculiarity is that after early sowing of spring barley, the development of the aboveground vegetative sphere of plants occurs under a different regime of light flux and temperature factor.

\section{Results of analytical studies}

Starting from 2010, in the selected growing zone of brewing barley cultivation, it has been set a regular possibility of barley sowing in the early terms, in particular, in the first or second decades of March. The advantage of this possibility is $70-75 \%$. 
Accordingly, the duration of vegetative development in barley under these conditions increases, which contributes to the enhancement of the biological potential, and therefore the yield of grain and its quality. As the period before the generative state of development becomes longer, so does the duration of tillering, which will lead to an increasing number of productive stems per unit area of sowing. The realization of the second element of the yield - the number of grains in the spike, will also be better to reach the full potential, as the duration of the second and third stages of organogenesis increases.

With the beginning of the formation of the generative sphere in plants determines the period of cone growth isolation of vegetative metamers, and the process of tillering. Short spring days cause weakening of the apical dominance of the main stem due to the ratio of stimulants and inhibitors of growth and development, which improves the possibility of full development of lateral stems. This helps to synchronize the formation of vegetative structures of the stem and spike to the parameters of the main. Thanks to such opportunities, crops of better optical density are formed under the influence of a short light period of day.

Tillering should be considered as the ability of barley plants under the conditions of coenotic competition to make the most efficient use of limited environmental conditions, ie factors of vegetation and, above all, light. In response to the alternation of light and dark throughout the day, barley belongs to plants for a long day.

Accordingly, in such circumstances, an important requirement in realizing the agro-potential of brewing barley in Ukraine should be the maximum possible provision of effective plant development from its inception, which also directly relies on cultivation technology. In this regard, it is necessary to pay attention to the biological characteristics of spring barley in relation to mineral nutrition. Within three weeks after germination, it is found that the barley absorbs $2 / 3$ of the total potassium demand, up to almost $50 \%$ of phosphorus, organic matter during this time accumulates less than a fifth, making it a short, intensive nutrient uptake and requires nutrient absorption the beginning of the growing season of a sufficient number of easily accessible elements of nutrition (Belyakov, 1990).

The moisture factor is one of the important factors in brewing barley growing in relation to malt quality. The biological optimum rainfall for spring barley in March-July corresponds to $250-390 \mathrm{~mm}$, the total water consumption according to the resources of the year is $450 \mathrm{~mm}$ for the western Forest-steppe, and the central one is $420 \mathrm{~mm}$ (Lipinski et al., 2003). Among cereals, it is considered to be one of the most drought-tolerant and belongs to crops that consume moisture sparingly, but barley is very sensitive to insufficient water supply to the stem elongation phase. It is established that with the beginning of the growth of the stem before the grain filling, the plants use a lot of moisture. Deficiency of which during this period leads to a sharp decrease in yield, and when ripe causes early aging of the vegetative organs, as a result of worsening of plastic substances to the grain, there are changes in the carbohydrate-protein complex, which result in defective grain filling. As a result, quality indicators, especially malty, are reduced (Lukyanova et al., 1990). However, a temporary shortage of moisture does not always lead to a decline in yield. The growth of spring barley grains can occur without interruption due to the water reserves of the upper part of the stem, although the activity of photosynthesis under the influence of adverse conditions is temporarily reduced (Bayer et al., 1984).

The formation of the third element of the yield structure, the mass of the grain when growing brewing barley is the most responsible final step in the development of quality. This is the period of accumulation of starch, the main component of extractivity. The lack of moisture in the soil during the formation and pouring of grain is influential in limiting the possibility of spreading the sown areas of brewing barley in Ukraine. It is established that the closest correlation of crop yields with moisture reserves in the meter layer of soil is observed during the formation of the elements of productivity of the spike. In accordance with the requirements of ensuring a high yield in stocks of productive moisture, they in this period make not less than 100-125 mm. According to many years of research, the optimal moisture reserves in the soil layer $0-100$ are in the range of $130-160 \mathrm{~mm}$ (Medvedev and Plisko, 2006).

Early sowing time contributes to the efficient use of the agrohydrological potential of the climate, since before the rising temperatures, the morphological structure of barley crops provides cover for the soil surface, which makes it impossible to increase soil moisture loss through evaporation.

Czech specialists pay attention to the dependence of the quality of brewing barley on moisture supply. They emphasize that grain development is largely determined by the amount of assimilates available. With insufficient supply of soil, the flow of assimilates to the reproductive organs is limited. Throughout the period from fertilization, the beginning of the formation of the grain to full ripeness, there are processes of accumulation of spare substances and processes of qualitative changes. The dependence of the increase in the dry matter of the kernel on the activity of cytokinins two weeks after fertilization, which are transported from the root system, was revealed. They came to the conclusion that cytokinins affect the size of the grain, directly due to the increase in storage capacity, and by inhibiting the aging of the spike and increasing the duration of dry matter accumulation. A divergence of the final mass of the grain was found, which positively correlates with the content of cytokinins. Cytokinins in chemical structure are derived from nitrogenous substances, purines. An important feature is that the accumulation of nitrogen in the grain to milk ripeness occurs when it is assimilated from the soil (Bayer et al., 1984). Accordingly, reserves of productive soil moisture play a particularly important role at this time in ensuring the metabolism processes associated with the final productivity of the spike, the third component of the yield structure. Thus, soil moisture is an important condition for brewing barley growing. It is believed that the western and central parts of the Forest-steppe, with reserves of productive moisture of $0-20 \mathrm{~cm}$ in the soil layer, are favorable for providing early spring crops (30-40 mm of available moisture). The main problem of agrarian production of Ukraine in the cultivation of early spring cereals is the lack of productive moisture in the soil layer $0-100 \mathrm{~cm}$ during the formation of productivity elements of the spike, in particular the mass of the grain, one of the rather important indicators of the structure of the crop, as mentioned above, associated with brewing quality of barley (Medvedev and Plisko, 2006). Soil moisture deficiency refers to the main limiting factor that determines the size of the crop in the areas with fertile soils. An important feature of spring barley in connection with the moisture content of the final period of crop formation is the established pattern of lower water consumption per unit of dry matter on fertile soils, especially at high agro-technology than on low-fertile soils (Osin, 1983). It is established that the minimum of moisture reserves according to long-term data we have in July. On light soils before harvest, productive moisture is fully used in Ukraine. The best soil productivity during the final stages of the formation of spring early cereals with $0-100 \mathrm{~cm}$ of soil moisture is characterized by black soil typical, representing the Forest-steppe subzones - first, second and third.

According to moisture reserves under early spring crops during the formation of the third crop component, in particular in barley, Lviv, Ternopil, Khmelnytsky, Vinnytsia, Chernivtsi regions are favorable under the Forest-steppe conditions of Ukraine, where the indicators for the long-term data for the third decade of June are from 100 to $160 \mathrm{~mm}$, for the first decade of July - from 100 to $160 \mathrm{~mm}$, for the second decade of July - from 100 to $160 \mathrm{~mm}$. Favorable conditions for moisture reserves in the meter layer of soil are in the Forest-steppe southern regions of Volyn and Rivne regions. Sufficient rainfall during the growing season is characterized 
by an average of 235 to 275 mm in Lviv, Volyn, Rivne, Ternopil, Khmelnytsky, Vinnytsia, Chernivtsi, Zhytomyr regions. The even distribution of rainfall by months is favorable for the development of barley (Table 1 ).

Table 1. Average annual of rainfall data for May-July in the characteristics of regions, $\mathrm{mm}$.

\begin{tabular}{llcl}
\hline Regions & May & Months & July \\
Volyn & 53 & June & 78 \\
Rivne & 52 & 77 & 77 \\
Zhytomyr & 53 & 67 & 78 \\
Lviv & 64 & 66 & 99 \\
Ternopil & 61 & 89 & 87 \\
Chernivtsi & 69 & 85 & 90 \\
Khmelnytsky & 51 & 86 & 85 \\
Vinnytsia & 59 & 73 & 72 \\
\hline
\end{tabular}

Observations over the period 2010-2019 have shown that early harvesting is often due to early sowing in the industrial zone of brewing barley. This is the first decade of July. In general, during early March sowing, crop formation promotes better soil moisture retention and utilization.

\section{The factor of heat supply}

Temperature is an important factor influencing the growth and development of barley in assessing Ukraine's agricultural potential. According to the idea of R.A. Reomiur the irreversibility of biochemical reactions in the growth and development of plants is determined by the cumulative action of thermal energy. Heat requirements are generally determined according to periods of growth and development. The heat demand of spring barley in the pre-sowing period is $2.5^{\circ} \mathrm{C}$. The biological minimum of the temperature factor for barley during which germination of sown seeds in the field occurs, and even less $-1-2^{\circ} \mathrm{C}$. Barley seedlings can withstand temperatures up to minus $7-8^{\circ} \mathrm{C}$. To ensure the complete cycle of development «sowing-wax ripeness» requires a biological sum of temperatures $1400-1500^{\circ} \mathrm{C}$ (Lipinski et al., 2003). Cooling and considerable moisture retard the growth of the especially aboveground part, the root system may develop at lower temperatures. According to I.B. Revut, the optimum temperature for germination of cereals plants is in the range of $5-15^{\circ} \mathrm{C}$, of which the least demanding for heat is barley, which corresponds to the lower level of values.

Barley is very sensitive to rapid heat build-up during the stem elongation phase, during the first stages of generative development. High air temperature and its sharp fluctuations during the period of crop formation have a negative effect on grain occupancy, their mass decreases, and brewing qualities deteriorate (Belyakov, 1990). It has been found that temperatures above $25^{\circ} \mathrm{C}$ can increase the flow of assimilates into the spike from other parts of the plant. Over a long period of such a temperature regime, the formation of grain and the aging of assimilating organs are accelerated, as a result, the total amount of assimilates decreases, and eventually the dry matter weight of the grain (Evans and Rawson, 1970).

The optimal conditions for the growth and development of barley are within the temperature range of $15-20^{\circ} \mathrm{C}$, during flowering the most favorable is the air temperature of $15-18^{\circ} \mathrm{C}$, and during the formation and filling of grain $18-20^{\circ} \mathrm{C}$. In order to obtain high yield and malt quality of barley, the uniform mode of grain filling process is of great importance (Lukyanova et al., 1990).

Today, it is recognized by experts that cereals, incl. of barley with the growth of the grain immediately begins to accumulate starch. Confirmation of this is the conclusions, where it is noted that the rate of dry matter accumulation of the barley grain formation phase cannot be separated from the grain filling phase (Borisonic, 1974). Creation of the grain capacity in the period of its formation is considered one of the main prerequisites for ensuring the possibility of intensive accumulation of plastic substances by the plant. Many researchers have paid attention to temperature as an important environmental factor determining the grain occupancy (Laman et al., 1987; Garmash, 2005; Tamaki et al., 2002; Passarella et al., 2008; Altenbach et al., 2003).

It is believed that to realize the potential of cereals in the period from flowering to waxy ripeness, a sum of effective temperatures is required, which is a stable indicator within $700^{\circ} \mathrm{C}$. The relative weight gain of barley grains per day of $1.5 \mathrm{mg}$ was established. Accordingly, the mass of the grain will increase over a longer period of plastic input to the grain. Thus, elevated temperatures contribute to the rapid collection of the required amount of effective temperatures, as a result, the grain filling period becomes smaller. In addition, it should be borne in mind that in the case of elevated temperatures during the development of cereals transpiration increases, the outflow of nitrogenous compounds increases in the first place to those organs, which are determined by high metabolic activity. Such organs during the flowering period and after its completion are spike and grains that develop in it (Bayer et al., 1984).

The conditions of heat supply in Ukraine for spring early cereals in general are favorable. Temperatures in the final period of early grain crop formation as a factor ensure a sufficiently high crop productivity, as favorable and satisfactory modes dominate in most of its territory (Medvedev and Plisko, 2006). Monthly average figures for May, June and July for the industrial zone of brewing barley are consistent with the intensive growth and development and the needs of the full formation of the third component of the structure of barley grain yield. According to the sequence of the above mentioned months of the year, the data in the Volyn region are $-13.6 ; 16.9 ; 18.6^{\circ} \mathrm{C}$, Rivne $-13.5 ; 17.0 ; 18.7^{\circ} \mathrm{C}$, Zhytomyr - 13.9; $17.1 ; 18.7^{\circ} \mathrm{C}$, Lviv - 14.8; $16.7 ; 18.5^{\circ} \mathrm{C}$, Ternopil $^{-13.5}$; $16.7 ; 18.2^{\circ} \mathrm{C}$, Khmelnytskyi $-13.5 ; 17.4 ; 18.9^{\circ} \mathrm{C}$, Vinnytsia $-13.6 ; 17.1 ; 18.7^{\circ} \mathrm{C}$. It should be emphasized that the arable land of Ukraine out of the total amount of 30.0 million hectares as the influence of temperatures for the cultivation of early spring crops in the assessment of flowering period - the formation of productive organs, as the most favorable occupy 2.58 million hectares $8.6 \%$, favorable -26.28 million hectares $-87.6 \%$ and satisfactorily characterized by 1.14 million hectares (Medvedev and Plisko, 2006). The peculiarity of the changes that have taken place in the last decade is the established pattern of early heat input, which is directly related to the brewery barley growing zone. In particular, if during the period from 2000 to 2009 , the favorable conditions of early sowing of barley in the beginning of March amounted to $20-25 \%$, then from 2010 to 2019 this possibility increased to $75 \%$ and more. According to the Kamianets-Podilskyi meteorological post, the average monthly temperature in March from 2010 to 2019 was $+3.0^{\circ} \mathrm{C}$ in 2010 , $\max -+18.7^{\circ} \mathrm{C}$; in $2011-+1.3^{\circ} \mathrm{C}$, $\max -+17.3^{\circ} \mathrm{C}$; in $2012-+5.2^{\circ} \mathrm{C}$, $\max -+19.2^{\circ} \mathrm{C}$; in $2013--1.0^{\circ} \mathrm{C}$, $\max$ $-+9.5^{\circ} \mathrm{C}$; in $2014-+6.6^{\circ} \mathrm{C}$, $\max -+20.6^{\circ} \mathrm{C}$; in $2015-+4.6^{\circ} \mathrm{C}$, $\max -+16.4^{\circ} \mathrm{C}$; in $2016-+5.0^{\circ} \mathrm{C}, \max -+20.2^{\circ} \mathrm{C}$; in $2017-$ $+6.8^{\circ} \mathrm{C}$, max $-+20.8^{\circ} \mathrm{C}$; in $2018--0.2^{\circ} \mathrm{C}$, $\max -+13.8^{\circ} \mathrm{C}$; in $2019-+5.5^{\circ} \mathrm{C}$, $\max -+22.0^{\circ} \mathrm{C}$. 
In the conditions of the southwestern part of the brewing barley growing zone for 10 years, the conditions for 2011,2013 and 2018 were unstable for spring field work in March. Only one of them in 2013 stands out for the fact that the maximum temperature did not reach the level of the active parameter $+10^{\circ} \mathrm{C}$ due to the influence on the development of spring barley. In 2011 , despite the unstable increase in heat, $17.3^{\circ} \mathrm{C}$ was higher than the active minimum $-7.3^{\circ} \mathrm{C}$, and in $2018-3.8^{\circ} \mathrm{C}$. This indicates that the conditions of these years required operative measures within a short time of sowing. Seven years out of 10 were the most favorable for early spring sowing in March.

Compared to the decade 2000-2009, when carrying out research with spring barley, the conditions for sowing came mainly in the first decade of April, and only three years out of ten sowing was conducted at the end of March twice - on the 28th and one - on the 30th of March.

According to the temperature regime, the favorable conditions for sowing spring barley were shifted 18-22 days earlier, according to the conducted observations and on the basis of experience exchange with production units of the agrarian sector. This ensured the complete vegetative development of the plants mainly 12-15 days earlier than the data recorded for the period 2000-2009, when this period was completed in the first decades of May, in separate years within the May 12-17.

Regarding the analysis of the data of the thermal regime in April 2010-2019, compared to the years 2000-2009, no significant deviations of the daily average temperature data occurred. According to the Kamyanets-Podilsky meteo-post, the 2000-2009 period is characterized by values ranging from 9.1 to $12.7^{\circ} \mathrm{C}$. For the period $2010-2019$, the data ranged from $+8.8^{\circ} \mathrm{C}$ to $+13.9^{\circ} \mathrm{C}$. According to the Rivne meteorological post, the northern part of the industrial zone of brewing barley in the period 2010-2019, the air temperature was in the range from $8^{\circ} \mathrm{C}$ to $13.4^{\circ} \mathrm{C}$, which, compared to the parameters of the last 10 years, shows the stability of heat supply in April.

Similarly, according to the Vinnitsa meteorological post, the eastern part of the zone of industrial production of brewing barley, for the period $2010-2019$, the interval of temperature changes ranged from $+8.5^{\circ} \mathrm{C}$ to $+13.3^{\circ} \mathrm{C}$, which corresponds to the temperature regime in April 2000-2009. Therefore, the thermal regime of the brewing barley growing area in April is stable. The parameters of the air temperature are within the optimal conditions for realizing the biological potential of spring barley during the II and III stages of organogenesis. It is established that a sharp rise in temperature to $15-20^{\circ} \mathrm{C}$ accelerates the development of the II and III stages of organogenesis, which does not contribute to the efficiency of the vegetative period in the formation process of the biological potential of barley.

Conducted recognition experiment showed that during sowing of spring barley in the first decade of March under the conditions of 2010-2019, the duration of tillering phenophase increased compared to crops, where the plants began their development in the first decade of April by 15 days. The difference is set according to 35 and 20 days. It is established that sowing with better characteristics of plant productivity is always formed in plants of barley during spring tillering.

Accordingly, the development of spring barley in early sowing in March, due to its biological characteristics, is favorable for ensuring the realization of plant potential.

According to the Lutsk meteorological post, from 2014 to 2019, the average monthly temperature in March was respectively from the north of the industrial zone of brewing barley in $2014:+6.5^{\circ} \mathrm{C},+36.8^{\circ} \mathrm{C} ; 2015+4.9^{\circ} \mathrm{C},+18.2^{\circ} \mathrm{C} ; 2016+4.0^{\circ} \mathrm{C},+13.7^{\circ} \mathrm{C} ; 2017$ $+6.1^{\circ} \mathrm{C},+18.1^{\circ} \mathrm{C} ; 2018+0.7^{\circ} \mathrm{C},+12.8^{\circ} \mathrm{C}$ and $2019+5.1^{\circ} \mathrm{C},+18.5^{\circ} \mathrm{C}$.

According to the Rivne meteorological post, the average monthly temperature in March 2010 was $+1.8^{\circ} \mathrm{C}$, maximum $-+17.8^{\circ} \mathrm{C}$; in $2011-+0.6^{\circ} \mathrm{C}$, maximum $-+17.6^{\circ} \mathrm{C}$; in $2012-+2.7^{\circ} \mathrm{C}$, maximum $-+18.8^{\circ} \mathrm{C}$; in $2013--3.4^{\circ} \mathrm{C}$, maximum $-+8.7^{\circ} \mathrm{C}$; in $2014-$ $+5.5^{\circ} \mathrm{C}$, maximum $-+21.1^{\circ} \mathrm{C}$; in $2015-+4.5^{\circ} \mathrm{C}$, maximum $-+17.6^{\circ} \mathrm{C}$; in $2016-+3.4^{\circ} \mathrm{C}$, maximum $-+13.1^{\circ} \mathrm{C}$; in $2017-+5.5^{\circ} \mathrm{C}$, maximum $-+18.0^{\circ} \mathrm{C}$; in $2018--1.8^{\circ} \mathrm{C}$, maximum $-+12.8^{\circ} \mathrm{C}$; in $2019-+4.3^{\circ} \mathrm{C}$, maximum $-+18.1^{\circ} \mathrm{C}$.

The temperature regime according to the ten-year data of Rivne meteorological post in 2011, 2013, 2018 was unfavorable for carrying out spring-field works in the first half of March. However, from the mentioned three years in 2011, the maximum temperature was recorded in the second decade, which was $17.6^{\circ} \mathrm{C}$, as in the second decade of 2018 it was $12.8^{\circ} \mathrm{C}$.

According to the Vinnitsa meteorological station, the average monthly temperature in March 2010 was $+9.4^{\circ} \mathrm{C}$, max $+21.3^{\circ} \mathrm{C}$; in $2011+0.6^{\circ} \mathrm{C}$, $\max +16.9^{\circ} \mathrm{C}$; in $2012+2.2^{\circ} \mathrm{C}$, $\max +17.2^{\circ} \mathrm{C}$; in $2013-2.1^{\circ} \mathrm{C}$, $\max +8.3^{\circ} \mathrm{C}$; in $2014+5.5^{\circ} \mathrm{C}$, $\max +18.8^{\circ} \mathrm{C}$; in 2015 $+4.0^{\circ} \mathrm{C}$, $\max +14.2^{\circ} \mathrm{C}$; in $2016+4.0^{\circ} \mathrm{C}$, $\max +16.6^{\circ} \mathrm{C}$; in $2017,+5.8^{\circ} \mathrm{C}$, $\max +18.4^{\circ} \mathrm{C}$; in $2018-1.9{ }^{\circ} \mathrm{C}$, $\max +12.2^{\circ} \mathrm{C}$; in 2019 $+4.6^{\circ} \mathrm{C}$, $\max +18.6^{\circ} \mathrm{C}$. Of the 10 years in the eastern part of the zone, only the conditions of 2011, 2013, 2018 did not provide sowing of spring barley in the first decade of March, and only one year in 2013 does not have the characteristics of active temperature parameters favorable for growth during this decade and development, that is, $10^{\circ} \mathrm{C}$ or more.

\section{Light factor}

The realization of the genetic potential of malting traits of brewing barley varieties that are determined by a large number of genes depends on the interaction of the genotype with the environment (Langer, 2003). According to the results of the scientific researches it has been proved that the orientation of photosynthesis is due to the age of the plant leaves and environmental conditions. In young leaves, photosynthesis contributes significantly to the formation of amino acids and proteins, as they age, the carbohydrate orientation of photosynthesis increases. Physiologists note that under conditions of medium-optimal light intensity, leaves retain their age-related orientation of photosynthesis and the better the illuminated leaves, the greater the photosynthesis of carbohydrates (Zlobin, 2004). Thus, attention is paid to the important role of light, as an environmental factor, in the biochemical orientation of metabolism processes. Sunlight is an important source of renewable energy that is transformed by plants and stored by chemical compounds in covalent bonds. It is established that the beam in the wavelength region of $380-740 \mathrm{~nm}$ is characterized by photosynthetic active radiation - the PAR (Zlobin, 2004). The bulk of scientific experiments on the effectiveness of sunlight is devoted to photosynthesis and the theory of obtaining high yields (Nichiporovich, 1956). In this aspect of research, scientists have also paid attention to the metabolism of plants depending on the radiation range. An ambiguous influence on the synthesis of action of waves of different lengths has been proved. It is revealed that ultraviolet, violet and blue rays (wavelength <400; 400-421; 424$491 \mathrm{~nm}$, respectively) affect the intensity and course of photosynthesis, in the process of which they promote the formation of proteins in chloroplasts and together with this accelerate the passage of the formation stages of reproductive organs. Red beams with wavelengths of $620-740 \mathrm{~nm}$ most actively contribute to the synthesis of carbohydrates, they contain the largest number of quanta in a unit of energy (it is proved that the photochemical effect is determined not by the energy of individual quanta, but by the number of such) when absorbed in plants there is no excess of «negative» thermal energy (Zlobin, 2004). In the intensity of absorption of solar energy, this process is best performed at a narrow wavelength of $600-680 \mathrm{~nm}$. 
Solar radiation is affected by the atmosphere. Water vapor, gas molecules absorb shortwave ultraviolet, violet, blue rays and transmit the longwave part of the spectrum. Accordingly, the light scattered through the clouds, enriched with respect to direct sunlight, is most important for photosynthesis with orange-red rays (Table 2). Thus, the direct sunlight incident on the leaf surface differs from the scattered one, which is characterized by a large proportion of rays contributing to carbohydrate synthesis and depleted by the fraction of waves contributing to the formation of proteins in chloroplasts.

Table 2. Factors of influence of crop formation and quality of brewing barley.

\section{PAR - Wavelength range 380-740 $\mathrm{nm}$, the most productive photosynthetic range 600-680 $\mathrm{nm}$}

Light

The light scattered by the clouds is depleted of shortwave rays and is represented by the orange-red spectrum. Contributes to the formation of quality brewing barley.

Orange - $2.0 \mathrm{eV} /$ quant; 585-647 nm.

Red $-1.82 \mathrm{eV} /$ quant; $647-740 \mathrm{~nm}$.

Red rays contain the largest number of quanta in energy units. (The photochemical effect Longwave $\quad$ of light is determined not by the energy of quanta, but by their quantity. A. Einstein). The red quanta do not leave excess heat and do not cause thermal overheating of the leaves. The biological orientation of the red part of the spectrum: the carbohydrate pathway of photosynthesis.

Ultraviolet $-4.88 \mathrm{eV} /$ quant, $<400 \mathrm{~nm}$.

Violet $-3.02 \mathrm{eV} /$ quant, $400-424 \mathrm{~nm}$.

Blue $-2.7 \mathrm{eV} /$ quant, $424-491 \mathrm{~nm}$.

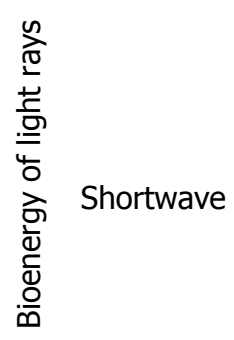

Wet

Warm
Blue-violet part of visible light: quanta, due to the excess energy they contain, causes thermal overheating of the leaves, enhances transpiration. The biological role of the blue part of the spectrum: promotes the synthesis of amino acids, substances of a protein nature.

Favorable moisture reserves in the $0-20 \mathrm{~cm}$ soil layer during the sprouts of $30-40 \mathrm{~mm}$. During the flowering, forming, ripening of the grain at least $100 \mathrm{~mm}$ in $0-100 \mathrm{~cm}$ soil layer. The need for precipitation for vegetation is $285-300 \mathrm{~mm}$.

Air temperature $15-20^{\circ} \mathrm{C}$. $>20^{\circ} \mathrm{C}$ increases during the tillering process the destruction of the inhibitors. The ratio of stimulants to inhibitors changes.

Strong carbohydrate orientation of photosynthesis is very important for barley because it is associated with all the quality indicators of which there are dozens. The process of forming the quality of brewing barley during plant development occurs in May and June. According to the ratio of monthly scattered radiation to total under average cloud conditions, the best characteristics of this period, according to the Ukrainian Hydrometeorological Research Institute, is the territory of the brewing barley growing zone in Ukraine. The corresponding figures for May are $54 \%$, in June - 52\%, which is the best favorable in Ukraine for growing barley.

It is also important to emphasize that with intense illumination in the process of photosynthesis $1-2 \%$ of the sun's radiation energy is used, at a lower intensity of up to $10 \%$, the rest is absorbed by the leaves and goes into thermal energy, which is expended for the transpiration of water and other physiological and biochemical processes (Nichiporovich, 1956).

Transpiration causes an aqueous stream in which the mineral compounds necessary for metabolism are dissolved and also protects the plants from overheating. In direct sunlight, leaf tissue is highly heated and water evaporation is enhanced. Enhanced transpiration affects the outflow, primarily of nitrogenous substances, to the most active metabolic organs (Bayer et al., 1984). Accordingly, it also leads to an increase in the protein content of barley, which can be a very important reasoned example of ecological plant physiology. It is established that from north to south the ratio of scattered light to direct sun in favor of the latter, which naturally causes changes in the protein-carbohydrate complex of crops.

Studies in southern Ukraine have shown a positive relationship between the sum of hours of sunshine and the protein content of the grain, explaining that the increased accumulation of nitrogen in plants is facilitated by short-wave illumination (380-470 Nm), whose intensity drops sharply in the cloudy days, resulting in syntheses nitrogenous substances are inhibited. Accordingly, the sunlight entering the green leaf of the plants by biological content may differ greatly as a result of changes in the composition of photosynthesis products. Scattered light in the process of plastic metabolism affects the synthesis of carbohydrates in cereals, direct sunlight, stimulates greater accumulation of proteins. This pattern is important in the area of brewing barley. For example, in the western and central Forest-steppe the duration of the sunshine in June and July is 260-270 and 270-280 hours, respectively, in the south of Ukraine, in Kherson, the duration of the sunshine in June - 311, in July - 350 hours, in Odessa - 305 and 349 hours respectively. This emphasizes that the distribution of solar radiation shows zoning. The radiation pattern shows the annual duration of sunshine, which varies slightly from west to east, while significant differences are observed from northwest to southeast. For example, in the western regions of the Polissia and the Forest-Steppe, the average sunshine averages 1690-1850 hours, while on the Black and Azov seas 2150-2450 hours, in the Steppe 2000-2200 hours (Lipinski et al., 2003). This pattern is characteristic of the period of vegetative development of spring crops. In particular, in July, when the final stages of the formation of spring barley crop on the third element are underway, on average for the years 1961-1990 the duration of the sunshine was 263 - in Kovel, 268 - in Vinnitsa, 318 - in Debaltsevo and 313 hours - in Odessa. Thus, the conditions of the Central and Western Forest Steppe are characterized by much less influence of solar radiation than the conditions of the Steppe of Ukraine, which corresponds to a large extent to the conditions of growing brewing barley. Soils are an important factor in analyzing the optimal conditions for growing barley in Ukraine (Lipinski et al., 2003).

\section{The role of soils}

Barley is quite sensitive to soil fertility. This is due to its biological characteristics, it has a root system of low level of absorption of hard-to-reach nutrients from soil. It is characterized by a short period of intensive accumulation of nutrients. High yields are formed on fertile, structured soils by loamy mechanical composition with a deep arable horizon on which it shows the best results not only in yield but also in grain quality. Fertile soils provide plants with a sufficient number of mineral nutrition elements (Baliuk et al., 2019; Sedilo et al., 2018; Uvarenko, 2018), moisture during the growing season, they have good physical and chemical properties, promote the development of a strong root system, normal air exchange, are characterized by the reaction of soil and soil solution, 
which is favorable for plants and microorganisms. As a result, soil fertility is determined by the optimum ability to ensure the effective development of plants throughout the growing season. Dry, acidic, sandy, loam, peaty, saline soils are not suitable for growing barley. Important in the characterization of soils is their capacity for early onset of physical ripeness in spring and to ensure the efficiency of plant development from the very beginning of the crop formation. Humus plays a significant role in soil fertility (Grishchenko et al., 2019). In this soil all the basic nutrients of plants and microorganisms are accumulated and stored for a long time. When mineralized, they go into accessible form and are used by plants. Black soils contain the largest humus reserves. In the decomposition of humus and organic residues, a lot of carbon dioxide is released, which, as a result of gas exchange, enters the atmosphere of the groundwater, which is the carbon source of the plants. The relevant types of soils largely represent the Foreststeppe sub-zones - PFS-2 and PFS-3, which are characterized by their strong, good and sufficient moisture content by hydrothermal coefficient (Polupan et al., 2005; Polupan et al., 2005).

\section{Characteristics of black soils fertility \\ Black soils - Accelerated early development \\ Fertility: Humus - 200-590 t/ha}

Soil structure: $\mathrm{pH}$ 6.8-7.5 - Conditions of intensive nutrient absorption: high heat absorption capacity, moisture capacity (1 m soil layer: up to 170-190 mm, waterproof lumpy and granular structure), porosity of arable horizon (50-60\%), density addition - 1.0-1.2 $\mathrm{g} / \mathrm{cm}^{3}$, high biological activity, active air mode, access of $\mathrm{O}_{2}$ to soil, release of $\mathrm{CO}_{2}$ into the atmosphere.

\section{Early spring ripeness}

The agricultural area of the brewing barley is represented by black soils and is estimated at about 2 million hectares. As a result, the potential for a dedicated area of annual production of brewing barley can be at least 2.5 million tonnes of grain. This level of productivity provides not only the internal market demand but also its partial realization on the world markets. The selected area of brewing barley is part of the fourth zone of specialization of Ukrainian agriculture - «Intensive beet, grain and fodder production», substantiated on the basis of objective compliance with the law of wide zoning (Polupan et al., 2005). The rest of the territories occupied by agricultural land, in particular arable lands of the forest-steppe, as well as similar to the steppe, with reserves of productive moisture in $0-100 \mathrm{~cm}$ soil are characterized as limiting the potential of varieties of spring barley in the period of completion of crop formation when harvesting in the structure of yield component - the mass of the grain, determining the quality index. In addition, the southern and south-eastern regions of Ukraine in the quality of sunlight are favorable for the accumulation of high protein crops. The western part of the Forest-steppe, represented by the territories of Lviv and part of Ivano-Frankivsk regions, does not meet the biological requirements of spring barley for the quality of the soil. Similarly, the Polissya zone does not meet the biological requirements of barley for soil fertility and their particle size distribution. The heterogeneity of the agronomic properties of the sub-soils of the Polesie zone determines the diversity of their productive capacity. Despite the fact that the sod-podzolized soils, which are presented in the Polissya zone as medium-loamy, carbonate species are favorable for high barley cultivation, they occupy very small areas and are characterized by poverty on such trace elements as boron, copper, especially zinc (Polupan et al., 2005; Nazarenko et al., 2006). The latter in the technological processes of beer production is important, as it promotes the activity of metabolism of bioproducts (with insufficient supply of zinc in the composition of brewing barley, the breeding of yeast slows down, with fermentation of the wort is incomplete recovery of diacetyl). According to the requirements of the Brewery Law in Europe, zinc is envisaged to be solved because of its obligatory content in raw materials, it is prohibited to use zinc chloride additives in the process and donor anode zinc (Kunze, 2001). The weighted average fertility score of the land's natural fertility for winter wheat for the brewing barley growing zone is 76-80, with an effective fertility of 96-100 points (Polupan et al., 2005). The productivity of spring barley by natural agro-soil potential for typical black soils may vary from 2.4-2.7 to 3.7-4.1 t/ha, depending on the particle size distribution (heavy sandy, light loam, medium loam, heavy loam), on black soils of 3.2-3.6 to 4.0-4.4 t/ha (Polupan et al., 2005).

\section{Conclusion}

Annual rainfall and even distribution throughout the growing season provide total water demand, and correspond to the biological optimum of spring barley. According to the reserves of productive soil moisture at the time of germination, the phenophases of the development of barley vegetative period, the generative and final period of crop formation, the conditions of the zone are characterized by favorable productivity of plants and quality of the grown products. In terms of temperature, the period of vegetation of spring barley prior to the onset of wax ripeness is ensured in accordance with the biological requirements of the culture for the heat demand of both early, middle and late ripening varieties. The average monthly air temperature in the conditions of the selected zone during the period of grain formation and filling is in the range from $16^{\circ} \mathrm{C}$ to $20^{\circ} \mathrm{C}$. According to the biological content of solar radiation, the conditions of the zone provide the advantage of accumulation of carbohydrates in cereals, the scattered radiation in the total is $50-52 \%$. In general, the favorable conditions for the productivity of spring barley of dedicated cultivated area is the highest in Ukraine and is $80-85 \%$. Thus, according to the signs, indicators and regularities, the agro-resources of the selected zone of brewing barley, determine the terms of the duration of growth and development of plants, formation of their productivity and quality of grain, are most favorable in the conditions of the territories of Ukraine. The soils of the brewing barley growing zone by their fertility, granulometric composition, humus content, physical and chemical properties, high heat capacity, reaction of soil solution, water and air regimes, high biological activity provide favorable barley development.

\section{References}

Altenbach, S.B., DuPont, F.M., Kothari, K.M., Chan, R., Johmson, E.L., Lieu D. (2003). Temperature, water and fertilizer influence the timing of key events during grain development in US spring wheat. Journal of Cereal Science, 37, 9-20. DOI: https://doi.org/10.1006/jcrs.2002.0483

Baliuk, S.A., Nosko, B.S., Shimel, V.V., Yeterevska, L.V., Momot, G.F. (2019). Optymizatsiia zhyvlennia roslyn u systemi faktoriv efektyvnoi rodiuchosti hruntiv [Optimization of plant nutrition in the factors system of effective soil fertility]. Bulletin of Agricultural Science, 3(792), 12-19. DOI: https://doi.org/10.31073/agrovisnyk201903-02 (in Ukraine)

Bayer, Ya., Cherny, V., Ferik, M. et al. (1984). Formirovanie urozhaya osnovnyh selskohozyaystvennyh kultur [Formation of the crop of basic crops]; trans. from Chech. Z.K. Blagoveshchnskaya. M.: Kolos, 28-29, 158-160, 161-165. (in Ukraine)

Belyakov, I.I. (1990). Yachmen v intensivnom zemledelii [Barley in intensive agriculture]. M.: Rosagropromizdat, 8-9. (in Ukraine) 
Blizniuk, B.V., Demidov, O.A., Kirilenko, V.V., Humeniuk, O.V., Kalitsinska, O.B. (2019). Vplyv agroekologichnyh chynnykiv i sortovyh osoblyvostej na vrozhajnist' ta yakist` zerna pshenyci myakoyi ozymoyi [Influence of agro-environmental factors and varietal characteristics on the yield and quality of soft winter wheat grain]. Agro-ecological journal, 1, 62-73. DOI: https://doi.org/10.33730/2077-4893.1.2019.163258 (in Ukraine)

Borisonic, Z.B. (1974). Yachmen yarovoy [Spring barley]. M.: Kolos, 58-297. (in Ukraine)

Evans, L.T., Rawson H.M. (1970). Photosynthesis and respirationby the flag leaf and ear components during development in wheat. Aust. J. biol. Sci., 23, 245-254.

Garmash, E.V. (2005). Temperature Controls a Dependence of Barley Plant Growth on Mineral Nutrition Level. Russian Journal of Plant Physiology, Vol. 52, No3, 338-344. DOI: https://doi.org/10.1007/s11183-005-0051-4

Grishchenko, O.M., Zapasny, V.S., Yarmolenko, E.V., Shilo, L.G. (2019). Dynamika rodyuchosti gruntiv Pereyaslav-Xmel 'nyczkogo rajonu Kyivs 'koyi oblasti [Soil fertility dynamics of Pereyaslav-Khmelnitsky district of Kyiv region]. Agro-ecological journal, 3, 35-41. DOI: https://doi.org/10.33730/2077-4893.3.2019.183469 (in Ukraine)

Křen, J., Dryšlová, T., Neudert, L., Lukas, V. (2013). Cereal Canopy Structure - Its Assessment and Use in Efficient Crop Management. Biomass Now - Sustainable Growth and Use; edited by Miodrag Darko Matovic, 35-74. DOI: https://doi.org/10.5772/54528

Kunze, V. (2001). Tehnologiya soloda i piva [Technology of malt and beer]; trans. from Germ. St. Petersburg: Profession Publishing House, 45, 51-54, 134-137, 144-149, 152, 181. (in Ukraine)

Laman, N.A., Yanushkevich, B.N., Khmurets K.I. (1987). Potentsial produktivnosti hlebnyih zlakov: Tehnologicheskie aspektyi realizatsii [Cereal productivity potential: Technological aspects of implementation]. Mn.: Science and Technology, 61-63, 95-97 181188, 204-208. (in Ukraine)

Langer, I. (2003). Basic principles of brewing barley selection. Beer and Life, 7, 13-23.

Lipinski, V.M., Diachuk, V.A., Babichenko, V.M. et al. (2003). Klimat Ukrayiny [Climate of Ukraine]. K.: Issue of Raevsky. P. 38-40, 42-47, 279-292. (in Ukraine)

Lukyanova, M.V., Trofimovskaya, A.Ya., Gudkova, A.Ya. et al. (1990). Kulturnaya flora SSSR [The cultural flora of the USSR]. L.: Agropromizdat, 240-241. (in Ukraine)

Medvedev, V.V., Plisko, I.V. (2006). Bonitirovka i kachestvennaya otsenka pahotnyih zemel Ukrayiny [Boning and qualitative evaluation of arable land in Ukraine]. Kharkov: 13 printing house, 80-95, 345-357. (in Ukraine)

Medvid, G.K., Boyko, P.I. (1993). Bioklimaticheskie printsipy spetsializatsii rastenievodstva i ustoychivosti zemledeliya [Bioclimatic principles of specialization of crop production and sustainability of agriculture]. Sustainability of agriculture: problems and solutions; edited by V.F. Saiko. K .: Urozhay, 90-113. (in Ukraine)

Nazarenko, I.I., Polchyna, S.M., Dmitruk, Yu.M. et al. (2006). Gruntoznavstvo z osnovamy geologiyi [Soil science with the basics of geology]: A textbook. Chernivtsi: Books-XXI, 312-314. (in Ukraine)

Nichiporovich, A.A. (1956). Fotosintez i teoriya polucheniya vysokih urozhaev [Photosynthesis and the theory of obtaining high yields]. M.: Publishing House of the USSR Academy of Sciences, 94 p. (in Ukraine)

Noworlink, K., Leszczynska, D. (2000). Reakcja nowych odmian jeczmenia jarego na gestosc siewy. Buil. Inst. hod. I aklim. Rosl., $214,143-158$.

Osin, A.E. (1983). Yachmen - vyisokourozhaynaya kultura [Barley is a high-yielding crop]. Mn.: Harvest, 8-9. (in Ukraine)

Passarella, Valeria S., Savin, Roxana, Slafer, Gustavo A. (2008). Are temperature effects on weight and quality of barley grains modified by resource availability? Australian Journal of Agricultural Research, Vol.59, No6, 510-516. DOI: https://doi.org/10.1071/AR06325

Polupan, M.I., Solovey, V.B. (1997). Priorytetnist` gruntovo-ekologichnogo rajonuvannya zemel 'nyh resursiv [Priority of soilecological zoning of land resources]. Bulletin of Agricultural Science, 4, 24-30. (in Ukraine)

Polupan, M.I., Solovey, V.B., Kisil, V.I., Velichko, V.A. (2005). Vyznachnyk ekologo-genetychnogo statusu ta rodyuchosti gruntiv Ukrayiny [Determinant of Ecological-genetic Status and Fertility of Soils of Ukraine]: A Handbook. K.: Koloobih, 106, 304. (in Ukraine)

Polupan, M.I., Solovey, V.B., Polupan, V.I., Velichko, V.A. (2003). Priorytetni klimatychni kryteriyi resursiv vologozabezpechennya, pryrody $\mathrm{j}$ energetyky gruntoutvorennya ta rodyuchosti gruntiv [Priority climatic criteria for soil moisture, nature and energy resources of soil formation and soil fertility]. Bulletin of Agricultural Science, 2, 13-19. (in Ukraine)

Polupan, M.I., Solovey, V.B., Velichko, V.A. (2005). Klasyfikaciya gruntiv Ukrayiny [Soil classification of Ukraine]. K.: Agricultural Science, 300p. (in Ukraine)

Polupan, M.I., Solovey, V.B., Velichko, V.A. et al. (2005). Specializaciya zemlerobstva - strategichna osnova pidvyshchennya efektyvnosti i stalogo rozvytku APK [Specialization in agriculture is a strategic basis for improving the efficiency and sustainable development of agriculture]. Bulletin of Agricultural Science, 5, 5-16. (in Ukraine)

Sedilo, G.M., Dubytska, A.O., Kachmar, O.J., Vavrynovych, O.V., Dubitsky, O.L. (2018). Rodyuchist' gruntu pid pshenyceyu ozymoyu za ekologichno bezpechnyh system udobrennya [Fertility of soil under winter wheat with environmentally friendly fertilizer systems]. Bulletin of Agricultural Science, 12(789), 19-25. DOI: https://doi.org/10.31073/agrovisnyk201812-02 (in Ukraine)

Tamaki, M., Kondo, S., Itani, T., Goto, Y. (2002). Temperature responses of leaf emergence and leaf growth in barley. The Journal of Agricultural Science, 138(1), 17-20. DOI: https://10.1017/S0021859601001745

Uvarenko, K.Yu. (2018). Vplyv ushchilnennya ta udobrennya gruntu na vykorystannya elementiv zhyvlennya i produktyvnist' yachmenyu yarogo [Influence of soil compaction and fertilization on the use of nutrients and productivity of spring barley]. Bulletin of Agricultural Science, 8(785), 76-81. DOI: https://doi.org/10.31073/agrovisnyk201808-05 (in Ukraine)

Zlobin, Yu.A. (2004). Kurs fiziologiyi i bioximiyi roslyn [Course in plant physiology and biochemistry]: A textbook. Sums: VTD «University Book», 116-117. (in Ukraine).

\section{Citation:}

Gorash, O., Klymyshena, R., Khomina, V., Vilchynska, L. (2020). Ecological and biological conformity of conditions of the brewing barley cultivation zone. Ukrainian Journal of Ecology, 10(1), 246-253.

(cc) $\mathrm{Br}$ This work is licensed under a Creative Commons Attribution 4.0. License 